\title{
SOME FEATURES OF STUDYING SEMANTIC STRUCTURE OF PHRASEOLOGICAL UNITS IN RUSSIAN AND UZBEK
}

\author{
Doronina Irina Nikolaevna
}

Lecturer Fergana State University, Uzbekistan

\section{ABSTRACT}

The article discusses the problems of comparative study of formal phraseology in Russian and Uzbek languages.

KEYWORDS :- Form phrases, base combination, semantic content, lexical-grammatical hierarchy, categorical delimitation, archetype, macrosema, phraseological-spiritual group

\section{INTRODUCTION}

The study of the semantic structure, as well as the formalization of phraseological units, requires a multifaceted, comprehensive approach, since its content side is hidden from direct observation. The study of the semantic side of phraseological units requires knowledge of the features of their structural and semantic organization. This article is aimed at describing units of one phraseological class, namely the adverbial phraseological units of the Russian language.

When determining the object of our research, we proceeded from the fact that adverbial phraseological units in both Russian and Uzbek languages are not given sufficient attention, although this category of phraseological units is quantitatively inferior only to verbal ones. In addition, they differ markedly from units of other phraseological and grammatical classes by their diverse semantic structure, grammatical structure and syntactic function (combinability, environment and distribution).
The allocation of adverbial phraseological units has been carried out for a long time and is typical for the system of both the Russian and Uzbek languages. But the bulk of the research devoted to the development of this problem was conducted on the material of the Russian language. And this is not surprising, because the formation of phraseology as an independent field of linguistics was the result of the works of Russian linguists and, first of all, the works of Acad. V,Vinogradov, which were fundamental for the comprehensive study of phraseology in general. He was one of the first to point out the existence of "idiomatic types of adverbs" in the language, which he considers from the point of view of their structural and grammatical arrangement and syntactic functioning. [1, 291].

\section{Materials AND Methods}

Phraseological units, as vocabulary units of a language, have much in common with words. But a closer examination of the meanings they express reveals that they also have a significant difference. 
In the semantic structure of phraseological units, two semes, as it were, coexist, one of which is a carrier of material meaning, and the other expresses additional shading values of the tone "very", "extremely".

Let's compare: quickly - in all the shoulder blades that there is urine, i.e. not just fast, but very fast.

Consequently, from the point of view of the internal content of phraseological units belonging to the category of adverbial ones, they consist of at least three elements: the seme of material content, the categorical seme and the amplifying seme.

However, the quantitative composition of semes in the semantic structure of NFE is not limited to the elementary units of meanings discussed above. Within one sememe, there are also semes that allow them to be grouped into a phrasesemantic group (FSG), subgroups and microgroups. For example, in units of the type: like the back of your five fingers, like a saddle on a cow, in all eyes, out of the corner of the eye, not for fear, but for conscience, through a tree stump, like a bird of heaven, not a sleeve for a fur coat, etc. - there is such an element of meaning that allows them to be combined into one group, although each of the presented NFE has a differential seme characteristic only of it; "Good", "bad", "attentively", "inattentively", "thoroughly", "carelessly", "arranged", "unsettled", etc. In this case, the unifying element is the qualitative characteristic of some action, state, expressed by them, and therefore they can be grouped into one FSH with the archiseme "quality". Unification in FSH, therefore, is carried out at a fairly general level: the seme "quality" is, as it were, directly adjacent to the categorical seme.

By FSH, we mean such a union of phraseological units, which is subsumed under some archiseme, enclosed in one way or another in each of the units assigned to it. When defining NFE according to semantic groups, a significant role is assigned to its vocabulary definition, some questions are also used that have a categorical feature (for example: when? Since when? - with a temporal meaning; where, from where? - with a spatial meaning, etc.)

\section{Results AND DISCUSSION}

At the next stage of the semantic classification of NFE, the values of a narrower range of units are detailed on the basis of highlighting a less abstract seme (macroseme). Thus, the archiseme "quality" includes such macrosemes as: "proper quality", "transmission of information", "quality of performance", "existence in the environment", which allow this FSG to be divided into four groups.

NFE with the "proper quality" macroseme, in turn, depending on the semantics they express, can be represented as an opposition of two specific semantic real meanings: "good", - "bad" (what is needed; God knows how).

The other three macrosemes have a more complex semantic structure, which makes it possible to isolate more semes of the third level: "concentration" and "inaccessibility" - in M - 2 (ie the "information transfer" macrosome), "diligence" and "complexity" - in M - 3 (that is, the "quality" macroseme of performance), "prosperity" and "consent" - for M - 4 (that is, the "existence in the environment" macroseme). Each of the seven third degree consists of a specific pair of the seven fourth degree, built on the basis of opposition.

Thus, the semantic classification of the NFE of the Russian language can be constructed according to the following scheme:

1) a border is drawn between the phraseological parts of speech, as a result of which the quantitative composition of 
the NFE is established;

2)

amplifying phraseological units are delimited, as a result of which only units remain in the field of our research, which express the real value;

3) the latter, by identifying the seed composition, are combined into FSH on the basis of an archiseme, which at this stage has a high degree of abstraction;

4) at the second stage, each FSH is delimited into separate subgroups on the basis of a macroseme, which already has a lower degree of abstraction and therefore combines a greater number of semantic features;

5) at the third level, within each subgroup, such types of NFE are distinguished that have a common seme of material meaning (seme) of the third level;

6) each seme of the third degree, as a rule, is built on the opposition of the meanings of two specific semes of material meaning (seme of the fourth degree);

7) in the subgroups allocated on the basis of the seme of real meaning (seme- 3 and seme-4), NFE are allocated, which are in synonymous and antonymic relations, synonymous-antonymic series are established.

The concretization of the semantic structure of the units under investigation, carried out at the last stage, is necessary, since it allows us to identify the syntactic capabilities of the NFE, establish the semantic volume of each of the units we have considered, and more accurately determine their material meaning. Moreover, when establishing synonymous and antonymic relations, we did not limit ourselves to only indicating the identity and opposition of the NFE. To identify the systemic relations between them, this is not enough, besides this "...... it is important to establish the fundamental difference between linguistic phenomena and the place of each of the phenomena in the general system of phraseology." $[2,67]$

Therefore, the semantic side of one or another FSH can be represented in the form of the following semantic "network":

The peculiarity of this semantic "network" is that its ramification depends on the number of archisemes, macrosomes and sem-3.

The content plan of the NFE of the Russian language, therefore, has a rather complex structure, which disintegrates as the abstraction of semantic features decreases into categorical seme, reinforcing sema, archiseme, macrosome, sema-3 and sema-4. At the same time, the seed composition of the material value of the NFE begins with the archeseme and the macroseme and, if possible, continues with the allocation of seme-3 and seme -4. In individual FSH, the seme of the fifth stage can also be distinguished, which unites a specific circle of sememes, which are synonymous with each other (for example: "near").

Attention should be paid to the fact that the differentiation of semes into integral (seme-3) and differential (seme-4) is conditional, because these concepts, depending on the level of hierarchical organization of the sememe, change their status, thereby showing the dialectical nature of linguistic meaning. As noted by N.V.Tsvetkov, "... the hierarchical organization of semantic elements is not absolute in the sense that the distinguished integral and differential semantic features are such only within the framework of a given sememe or FSG" [3, 67].

It should be noted that the microgroups allocated on the basis of the integral seme, referring to some macrofamily, constitute one opposition. At the same time, the opposition is manifested more 
clearly if phraseological units referring to two opposed microgroups are able to combine with the same word or, in extreme cases, with words that are in the same semantic area. When these conditions are met, phraseological units in opposition can easily enter into antonymic relations with each other.

Determining the correspondence of the external grammatical form of the phraseological unit and its semantic structure arising from the content of the whole phraseological unit as a whole, we established the degree of isomorphism between the plane of expression and the plane of content. The adverbial phraseological units of both the Russian and Uzbek languages have not yet been considered from these positions as an integral phenomenon, although to one degree or another this problem is touched upon in separate works, in particular, devoted to the categorical differentiation of phraseological units (N.M.Shansky, V.P.Zhukov, A.M.Melerovich, V.A.Yatselenko and others). However, in these studies, this issue is not always resolved consistently and clearly enough.

It should be noted that the study of the features of the ratio of the form and content of phraseological units has its supporters and opponents. So, a prominent representative of the first direction is A.M.Melerovich, who believes that "... the segmentation of phraseological units in terms of expression into word forms and combinations of lexemes creates conditions for the parallel division of the content plan into semantic segments corresponding to individual lexical components or combinations of components in the composition FE " [4, 69].

A.V.Zhukov speaks from opposite positions, according to which non-systemic meanings "are subjectively assigned or imposed on the components after the phraseological unit has been formed, and for this reason do not have predictive power" $[5,9]$. We also adhere to the latter point of view and, speaking about the isomorphism of form and content, we mean the predictable nature of only the categorical belonging of one or another phraseological unit based on the plan of its expression.

$\mathrm{PU}$, being the nominative units of the language, contain several full-valued words in their grammatical structure. According to the definition of Sh.U.Rakhmatullaev, phraseological units in their composition should have at least two lexemes related to the significant parts of speech $[6,4]$. At the same time, it should be borne in mind that the general, integral meaning of phraseological units does not follow from a simple addition of the values of its constituent components, as a result of which a new integral phraseological meaning is formed, which, as it were, is superimposed on the primary image, the meaning of its lexemes. When referring phraseological units to the corresponding phraseological and grammatical class, we, first of all, are based on this meaning, or rather on the categorical seme, contained in the semantic structure of this phraseological unit. The categorical seme is, as it were, a starting point for categorical differentiation of phraseological units.

On the other hand, in determining the belonging of phraseological units to the corresponding phraseological and grammatical class, an essential role is played by its external grammatical form and, to a large extent, the grammatical meaning of its supporting component. By the latter, we mean such a word in the structure of phraseological units, which performs the function of the grammatical center of a given unit. It, dominating the other components of phraseological units, gives them certain grammatical forms. Consequently, the grammatical support component (hereinafter referred to as GOC) contains the grammatical functions of the whole phraseological unit as a 
whole. Therefore, we will establish the degree of isomorphism of the categorical meaning of adverbial phraseological units, relying, as a rule, on the GOC. In this case, one should take into account, firstly, to which part of speech the word that acts as a GOC belongs to, its paradigmatics; secondly, the lexical meaning of the GOC itself, expressed by it when freely used (for example: the spilled sea, the devil's abyss; bir chimdim, daryodan bir tomchi, etc.).

The definition of GOC for both languages is solved in different ways: in the Uzbek language it is established easier than in Russian (with the exception of phraseological units, built according to the type of sentences). The main grammatical load in Uzbek phraseological units is carried by their last component. The post-positivity of the GOC in the Uzbek phraseological units is associated with the peculiarities of the structure of the language itself.

In the circle of phraseological units of the Russian language, GOC, due to its not being fixed in a certain position, is determined differently for different units. It is easier to establish in phraseological units, genetically derived from phrases with a subordinate connection, somewhat more difficult - with a compositional one. The reason for this is the equivalence of the connecting elements of the latter. But, on the other hand, each element (word) of this kind of phraseological unit is potentially a GOC.

In addition to the indicated types of adverbial phraseological units, it is customary to distinguish units with a sentence structure in phraseology. The criterion for this is a purely formal feature, namely: the presence in their composition of components that are among themselves in relation to the subject and predicate. Consequently, in such units, as it were, two grammatical centers coexist, thereby complicating the definition of GOC. In them, as a
GOC, we mark the verb or its functional form, which acts as a predicate, because it takes a stronger position. For example, phraseological units of the comparative construction of the Russian and Uzbek languages are classified by us under the heading with the degree of isomorphism 0.6-0.7. The criterion of their adverbialness is the external grammatical form, more precisely the affix -dai // - dec and the union as. But the role of the circumstance for them is not absolute, in some cases they are realized with other categorical meanings. (as black is white; ўрта қўлдай и т.п.). Therefore, their predictability is somewhat lower than that of phraseological units with adverbial and adverbial affixes.

\section{Conclusion}

In this work, we will dwell in detail on adverbial phraseological units with an explicitly expressed meaning.

This group is represented by units, the degree of isomorphism of the categorical meaning of which is conventionally equal to I.0. Adverbial phraseological units of this kind, depending on their structural and grammatical composition, we subdivide into two microgroups, which have barely noticeable differences in the degree of isomorphism they are opposed to.

I) PU, the adverbialness of which is predicted by its grammatical structure. Units of this kind consist of a combination of two full-valued words belonging to the lexico-grammatical category of adverbs. Consequently, here the categorical meaning of adverbial phraseological units is motivated, first, by the categorical meaning of lexemes; secondly, the external grammatical form; thirdly, the meaning of the lexeme in its free use. The components of the units included in this microgroup can be built on the basis of a connecting or subordinate relationship: sideways 
and indeed, all the time, this and that, day and night, God knows how, how much in vain; бугун эмас эртага, бирда эмас бирда, боятданбери, наридан бери, аввалдан абад еtс. (28; 7ед.). As can be seen from the examples, the units included in this microgroup consist of two lexemes belonging to the class of adverbs, therefore, the type of their connection does not play a significant role in assigning such phraseological units to the category of adverbs.

2) PU, the categorical meaning of which is clear enough, as in the previous type of units, is predicted by its external grammatical form. However, here the degree of isomorphism is established only on the basis of GOC. This component is expressed by an adverbial lexeme. The presence of a GOC and its establishment in such adverbial phraseological units is associated with the nature of the connection between its members. In all units introduced into this microgroup, there is a dependence of one component on another. The leading role in this is played by the GOC, and all its other members are completely subordinate to it, thereby predetermining the paradigm of the whole phraseological unit as a whole. In addition, the case form of a noun combined with it can indirectly indicate the adverbialness of a given unit.

a) PU, the dependent component of which is expressed by a noun in the instrumental case, and in the Uzbek - the original one: upside down, upside down, upside down, with grief in half; кўздан нари, жинидан баттар, бирдан олдин бирдан кейин etc. (6;7 units.). The degree of isomorphism of such units will be slightly higher than the others, since the instrumental and original case affixes are, as it were, an additional formal indicator of the adverbiality of similar phraseological units due to their great tendency to express the function of the circumstance.
Б) Phraseological units, the dependent component of which is expressed by nouns in various case forms: above the head, worse than expectation, at random, lazarus, on the side of the heat, a little light, easier than a steamed turnip; kuni kecha, bir sidirғa, ajalidan besh kun burun, etc. $(13 ; 12$ units.).

Thus, the adverbial phraseological units, the categorical meaning of which is expressed explicitly, in the Russian language there are 47 units, and in the Uzbek language - 26. Not all units included in this group have exactly the same degree of isomorphism. Some adverbial phraseological units consist only of adverbial lexemes and therefore exhibit a high degree of isomorphism, while in other units the categorical meaning is established only on the basis of the GOC, which is the adverb, as a result of which isomorphism is expressed somewhat weaker in them. It should be noted that in the Russian language the first type of phraseological units (28; I9 units) prevails, and in Uzbek, on the contrary, there are more units of the second type $(7 ; 19$ units).

\section{ReFERENCES}

1. Vinogradov V.V. Russkiy yazik (grammaticheskoye ucheniye o slove). - M.: Visshayashkola,1972.

2. Stishkova L.I. Semanticheskiye polya vo frazeologii sovremennogo angliyskogo yazika. - Vsb.: Obrazovaniye I funktsionirovaniye frazeologicheskih yedinits. -Rostov, 2001.

3. Tsvetkov N.V.K metodologii komponentnogo analiza // Voprosi yazikoznaniya, 1984.

4. Melerovich A.M. Semanticheskiy analiz frazeologicheskih yedinits // 
CURRENT RESEARCH JOURNAL OF PEDAGOGICS 2(6): 101-107, June 2021

DOI: https://doi.org/10.37547/pedagogy-crjp-02-06-20

ISSN 2767-3278

(C)2021 Master Journals

Crossref doi) 81 Google

Accepted 18 $8^{\text {th }}$ June, 2021 \& Published 23 $3^{\text {th }}$ June, 2021

Filologicheskiye nauki. 2009. №-5.

5. Jukov. A.V.K voprosu o frazeologicheskoy perehodnosti // Aktualniye problemi russkoy frazeologii. - L.: Izd.LGPI, 1983.

6. Rahmatullayev Sh.O'. O'zbek tilining izohli

frazeologik lug`ati. T.: O`qituvchi, 1978. 